\title{
TOŻSAMOŚĆ I GODNOŚĆ W ŚWIECIE WSPÓŁCZESNEJ POLITYKI
}

\begin{abstract}
Francis Fukuyama, Tożsamość. Współczesna polityka tożsamościowa i walka o uznanie, Rebis, Poznań 2018, ss. 224.
\end{abstract}

Od czasu wydania Końca historii Francis Fukuyama publikuje książki, które nawet jeśli nie końca przekonywają, to niewatpliwie trafiaja w sedno najważniejszych problemów politycznych współczesności. Tak jest również z jego Tożsamościa, praca powstała, jak pisze sam autor, pod wpływem wrażenia, jakie zrobił na nim wybór Donalda Trumpa na urząd prezydenta Stanów Zjednoczonych. W tekście Fukuyamy widać pasję polemiczna, gdy charakteryzuje Trumpa jako człowieka najmniej nadającego się na stanowisko prezydenta USA, gdyż pozbawionego „elementarnej uczciwości, rzetelności, zdrowego rozsądku, oddania interesowi publicznemu i wrodzonego kompasu moralnego”, zawdzięczającemu swą karierę temu, że „uprawiał głównie autoreklamę i bez skrępowania wykorzystywał wszelkie sposoby, żeby obejść stojących mu na drodze ludzi lub niewygodne przepisy"1. Być może tak było, ale czyż charaterystyka ta nie pasuje do wielu innych współczesnych polityków, także tych reprezentujacych liberalna demokrację?

We wstępie Fukuyama brnie dalej w tego rodzaju publicystykę, piszac, iż „Trump reprezentuje w polityce międzynarodowej szersza tendencję polegająca na zwrocie ku czemuś, co nazywane jest populistycznym nacjonalizmem"2, a reprezentowanym także rzekomo przez Władimira Putina w Rosji, Tayyipa Erdoğana w Turcji, Victora Orbána na Węgrzech, Jarosława Kaczyńskiego w Polsce i Rodrigo Duterte na

\footnotetext{
${ }^{1}$ F. Fukuyama, Tożsamość. Współczesna polityka tożsamościowa i walka o uznanie, Rebis, Poznań 2018, s. 10.

Ibidem.
} 
Filipinach. Zestawienie tak różnych typów przywództwa i systemów politycznych, które sa tworzone w wymienionych krajach, pod jednym szyldem „populistycznego nacjonalizmu” mogłoby skłonić czytelnika do rezygnacji z lektury, gdyż mało w nim przenikliwości i głębi.

A jednak w dalszych partiach książki Fukuyamy pojawiają się wątki warte refleksji. Dość nieoczekiwanie autor odwołuje się do antropologii i greckiego pojęcia thymos, a więc tej części duszy, która wedle starożytnych Greków pragnie uznania. Izotymia to więc pragnienie bycia szanowanym na równi $z$ innymi, a megalotymia to chęć bycia uznanym za kogoś lepszego od innych. Pytanie, które frapuje Fukuyamę, brzmi: czy współczesny system liberalnej demokracji, powiąanej z gospodarka rynkowa zapewnia odpowiednie ujście dla megalotymii ${ }^{3}$. Jest to pytanie niezwykle istotne, choć wyczerpująca odpowiedź na nie wymaga bliższego przyjrzenia się liberalnej demokracji i wolnemu rynkowi. Fukuyama przyjmuje milcząco dość idealistyczne rozumienie obu tych pojęć, podczas gdy ani liberalna demokracja nie jest tak liberalna i demokratyczna, ani wolny rynek nie jest tak wolny, jakby to wynikało $z$ ich potocznego rozumienia. Ryszard Legutko twierdzi nawet, że „liberalna demokracja stanowi poniekąd większą mistyfikację ideologiczna niż socjalizm", a krytykiem liberalnej demokracji sa także między innymi Fareed Zakaria oraz konserwatywni myśliciele francuscy ${ }^{4}$.

Pierwsza wątpliwość nasuwa się przy refleksji nad wynikami różnych głosowań. Jak to jest, że jedna większość - na przykład większość Parlamentu Europejskiego - jest słuszna, a inna - na przykład większościowa podstawa rządu Victora Orbána na Węgrzech czy PiS w Polsce - jest niesłuszna? Dlaczego wola obywateli wyrażona w demokratycznym ze wszech miar referendum francuskim czy holenderskim, by odrzucić „konstytucję europejska”, została zignorowana, a następnie ugniatana propagandowo w celu jej zmiany?

Parlament Europejski, podobnie jak wiele parlamentów państw członkowskich Unii Europejskiej, jest od dziesięcioleci zdominowany przez kartel dwóch partii: Europejskiej Partii Ludowej - dawniej nazwanej chadecja, choć od dawna $z$ chadecja nie ma ona wiele wspólnego - oraz europejskich socjalistów. Aby wygrać większość głoso-

Ibidem, s. 15 .

4 R. Legutko, Triumf człowieka pospolitego, Zysk i S-ka, Poznań 2012, s. 40. Por. też np.: F. Zakaria, Przyszłość wolności. Demokracja nieliberalna w Stanach Zjednoczonych i na świecie, Oficyna Wydawnicza Multico, Warszawa 2018; Ch. Delsol, Kamienie wegielne, „Znak”, Kraków 2018; É. Zemmour, Krytyka religii postępu, „Wszystko co najważniejsze” 2019, nr 18. 
wań wypracowały one uśrednione stanowisko, które nazwać można europejskim mainstreamem, a które coraz bardziej przesuwa się ku „politycznej poprawności”. Czy to już totalitaryzm? Może jeszcze nie, ale dziwić może łatwość, $z$ jaka przedstawiciele rządzących karteli rozgrzeszają komunizm, a tropia przejawy rzekomego „faszyzmu” tam, gdzie odzywa się wątpiący lud wyborczy. Notabene, wielu działaczy komunistycznych lub skrajnie lewackich idealnie przystosowało się do liberalnej demokracji i udaja, że zawsze byli po jej stronie. Wystarczy przypomnieć młodość Daniela Cohn-Bendita, Catherine Ashton, José Manuela Barroso czy Federiki Mogherini. Nic dziwnego, że europejska elita sprzeciwia się wyplenieniu resztek systemu komunistycznego wszędzie tam, gdzie są one widoczne.

Za wspólny mianownik ideologii komunistycznej i liberalno-demokratycznej można uznać przekonanie, że należy nie tylko brać udział, ale kierować radosnym „pochodem ku przyszłości”, że trzeba realizować „postęp”. Obydwie ideologie zawierają też „inżynieryjne” podejście do rzeczywistości społecznej, a oponentów traktuja jak szkodników, których należy wyeliminować. Dawniej była to „reakcja” lub „idealizm”, dziś jest do „przesąd”, „Ciemnogród” czy „faszyzm”. Jasnym słowem była i jest „nowoczesność”. Jedna i druga ideologia zachęca do „wybierania przyszłości”, ale także do kształtowania przeszłości. Stąd tak częsta niechęć skrajnych rzeczników liberalnej demokracji do obiektywnego przedstawiania historii, a nawet w ogóle do zajmowania się nią. Specyficznie opowiedziana historia ma bowiem służyć ukształtowaniu radosnej przyszłości. Najlepsza ilustracją tego jest Dom Historii Europejskiej w Brukseli. Innym wspólnym mianownikiem ideologii komunistycznej i liberalno-demokratycznej jest przekonanie o bezalternatywności tworzonych przez nie systemów, a więc pogląd, że historia jest procesem koniecznym, że rozwija się od czegoś gorszego do lepszego, pod warunkiem jednak, że procesem tym kieruje „nowoczesna” elita.

Klasyczny system demokratyczny opierał się na władzy ustawodawczej, wykonawczej i sądowniczej wybieranej bezpośrednio lub pośrednio przez obywateli. Jak jednak ocenić jakość wyborów $\mathrm{w}$ systemie liberalno-demokratycznym, w którym opinia publiczna sterowana jest przez media, a te $z$ kolei maja ogromny zwiąek $z$ największymi grupami kapitałowymi i w którym to niezależną często rolę odgrywaja służby specjalne, zdolne pozyskiwać ogromne zasoby informacji o obywatelach oraz o mechanizmach rządzacych mediami i biznesem? 
Można mieć także wątpliwości co do tego, jaki „wolny rynek” funkcjonuje obecnie w liberalnych demokracjach. Określenie „niewidzialna ręka rynku", użyte po raz pierwszy przez Adama Smitha w jego Badaniach nad natura i przyczynami bogactwa narodów (1776), weszło do kanonu myśli liberalnej i stało się zawołaniem wojowników o wolność gospodarczą. Nie zauważają oni jednak często, jak dalekie jest to hasło od rzeczywistości gospodarki poczatku XXI wieku. Od czasów rozkwitu gospodarki wolnorynkowej w XIX wieku nastąpił bowiem burzliwy rozwój wszelkiego rodzaju monopoli i aktywnej polityki gospodarczej państwa. Od czasu Wielkiego Kryzysu (1929-1933) realizowane sa rozliczne projekty wspierania popytu w postaci programów społecznych w myśl teorii Johna Maynarda Keynesa, programów naukowych na „badania i rozwój”, a także zbrojeń.

Jeśli zastanowić się nad rolą monopoli we współczesnym świecie, można sobie zadać pytanie, skąd się bierze polityka większości firm produkujących dobra konsumpcyjne, by skracać ich przydatność, albo w sensie materialnym, albo w sensie subiektywnego przekonania o tej przydatności. Otóż pierwsze porozumienie, w którym świadomie ograniczono trwałość produktu była umowa zawarta przez koncerny General Electric, Philips i Osram w 1932 roku o planowym postarzaniu żarówek i zachęcaniu klientów do kupna nowych wersji. Obecnie praktyki takie sa stosowane na masową skalę nie tylko $\mathrm{w}$ przemyśle elektronicznym, ale także odzieżowym oraz w produkcji artykułów gospodarstwa domowego i wielu innych dziedzinach.

Innym zjawiskiem, które ogranicza wolność gospodarcza, jest urabianie klienteli przez wielkie korporacje znajdujące się w pozycji monopolistycznej. Po raz pierwszy na pomysł wywołania „paniki” żywieniowej wpadli amerykańscy lekarze i farmaceuci z Metropolitan Life Insurance w 1945 roku. Odtąd jesteśmy bombardowani informacjami o tym, jak należy się zdrowo odżywiać, przy czym wiele $z$ tych informacji jest po prostu nieprawdziwych, gdyż maja one na celu wywołanie „powtarzalnego zainteresowania”, czyli uzależnienia klienta. W 1980 roku zapoczątkowano w USA na większą skalę akcję prowokowania klientów do zakupu leków. Odtąd przemysł farmaceutyczny skutecznie korzysta $z$ „paniki” zdrowotnej, a obywatele nabywaja coraz więcej nie zawsze potrzebnych, ale stale nowych leków. Bardziej wieloznaczne okazały sie metody nowej organizacji pracy w postaci modelu $7 \mathrm{~S}$ wprowadzone do wielu firm w 1979 roku za sprawa inicjatywy Toma Petersa i Roberta Watermana, którzy chcieli uwolnić innowacyjność pracowników przez wyzwolenie ich ze sztywnych struktur organiza- 
cyjnych korporacji. Pouczający jest też przykład sukcesu i problemy wywołane przez firmę Uber ${ }^{5}$.

Jeszcze bardziej skomplikowanym zjawiskiem współczesnej gospodarki światowej jest handel ryzykiem, nasilajacy się od lat siedemdziesiatych, a także wyrafinowane praktyki unikania opodatkowania, stwarzajace kłopoty jednym podmiotom i dajace nadzwyczajne zyski innym. Okazuje się też, że kryzys 2008 roku, wywołany nadużyciami w sektorze gospodarki wirtualnej, nie tylko nie ograniczył tego sektora, ale zyskał on wsparcie ze strony polityków decydujacych o finansach publicznych. W wyniku lobbingu okazało się, że państwo stało się obrońca interesu bogatych, a nie biednych. W czasach, gdy bogatsi bogacili się szybciej niż biedni, pewną nadzieję dawała praktyka lat osiemdziesiątych, gdy małe firmy komputerowe, posiadające oryginalny pomysł, zaczęły wygrywać konkurencję z korporacjami. Problem w tym, że osiagając prawdziwy sukces, mała firma zamienia się szybko w wielka korporację. Kariery Billa Gatesa, Steve'a Jobsa były tego najlepszym przykładem. „Niewidzialna ręka rynku” odziana jest więc dziś najczęściej w rękawicę państwa lub wielkich korporacji międzynarodowych.

Odpowiedź na pytanie postawione przez Fukuyamę, a więc pytanie o to, czy system liberalnej demokracji i wolnego rynku sprzyja megalotymii zależy więc w dużej mierze od tego, jak oceniamy ten system, a poza tym od tego, czy uznajemy megalotymię za zjawisko pożądane, czy nie. Zważywszy na zasięg manipulacji stosowanej we współczesnym świecie cyfrowym ${ }^{6}$, a także asertywność, będąca główna „cnota” tego świata, można by twierdzić, że magolotymia jest wręcz głównym schorzeniem systemu liberalnej demokracji. Współczesne elity biznesowe, polityczne i medialne wywieraja bowiem ogromna presję na „szarego człowieka”, który robi wszystko co się da, by zostać zauważonym. Presja ta ma zreszta dwoisty charakter. $Z$ jednej strony polega na częstym ignorowaniu woli wyborców, $z$ drugiej zaś strony na stymulowaniu postaw godnościowych przez reklamy w rodzaju „zasługujesz na więcej”. Nie dziwi więc twierdzenie Fukuyamy, że „żądanie uznania tożsamości jest główną idea, która łączy wiele $z$ tego, co się obecnie dzieje w światowej polityce"7. Tyle, że twierdzenie to należy uściślić.

\footnotetext{
5 J. Peretti, Zakulisowe umowy, które zmienily świat, Dom Wydawniczy Rebis, Poznań 2018, s. 64-69.

Por. np.: C. Wardle, Nowy nieporzadek świata, „American Scientific” 2019, nr 10,

7 F. Fukuyama, Tożsamość..., s. 16.
} 
Główna przesłanka historycznej analizy Fukuyamy brzmi: „mniej więcej w środku drugiej dekady dwudziestego pierwszego wieku polityka światowa uległa dramatycznej zmianie" $z$ efektami spekulacyjnego kryzysu lat 2007-2009 i stagnacja dochodów klasy średniej, a jej przejawem miał być sukces wyborczy Donalda Trumpa, brytyjskie referendum, które zadecydowało o Brexicie, oraz „cofnięcie się" dobrze prosperujacych liberalnych demokracji w Turcji, Tajlandii, na Węgrzech i w Polsce ku autorytaryzmowi ${ }^{9}$. Tylko słabej znajomości realiów Polski i Węgier można przypisać porównanie tych krajów do Turcji lub, co gorsza, putinowskiej Rosji, niemniej sam fakt poważnych zmian w wymienionych przez Fukuyamę krajach nie ulega wątpliwości. Pytanie oczywiście, jakie sa przyczyny i istota tych zmian. Nie jest bowiem przypadkiem, że Fukuyama pominą $\mathrm{w}$ tym zestawieniu polityczne i socjalne problemy Francji i Niemiec. Ich natura świadczyć bowiem może o czymś przeciwnym do jego tezy, a więc o tendencjach autorytarnych w samej demokracji liberalnej. Autor zauważył antyimigranckie tendencje w Europie Zachodniej i lewicowe skłonności do forsowania tożsamości ciagle nowych grup rzekomo „upośledzonych” przez system, ale przez dużą część ksiażki wydawał się nie doceniać roli „politycznej poprawności” w powstaniu nowej, prawicowej fali polityki „godnościowej”.

W kolejnych rozdziałach Fukuyama przygląda się przyczynom zjawisk, które zrewolucjonizowały życie społeczne Zachodu ostatnich dekad. Słusznie zauważył, że żądania „małżeństw” homoseksualnych wzięły się nie $z$ chęci skorzystania $z$ niektórych praw małżeńskich przez pary homoseksualne, ale $z$ ich żądania, by zyskać uznanie równej godności z parami heterseksualnymi. Zaraz obok omawia jednak także przesłanki ruchu $M e$ Too, powstałego po ujawnieniu skandalicznego postępowania hollywoodzkiego producenta Harveya Weinsteina wobec wielu aktorek. Te dwa przykłady pokazuja, jak z różnymi zjawiskami mamy do czynienia. Jeśli w obydwu przypadkach chodzi o godność lub szacunek dla osób cierpiacych jakieś niedogodności z powodu swej sytuacji życiowej lub zawodowej, to warto zapytać, jak rozumieć ową godność. Sytuacja, w której ktoś ma możliwość wykorzystywania swej pozycji, żeby dawać pracę za seks, jest bowiem

\footnotetext{
Ibidem, s. 19.

9 O źródłach informacji Fukuyamy o Polsce świadczyć może jego argument o tym, jak to 2018 roku, w rocznicę odzyskania niepodległości przez Polskę, 60 tysięcy Polaków maszerowało w Warszawie pod hasłem „białej rasy”. Ibidem, s. 154. Najwyraźniej Fukuyama zaczerpnał tę wiedzę $z$ przemówienia Guya Verhofstadta w Parlamencie Europejskim, a nie $z$ miarodajnych mediów.
} 
całkiem odmienna od sytuacji, w której brak niektórych uprawnień odczuwany przez pary homoseksualne prowadzi nie do praktycznych rozwiązań usuwających ten brak, ale do żądania zrównania w pełni praw, które ze względu na naturę nie sa równe.

$Z$ ksiażką Fukuyamy jest bowiem problem. Autor ten używa określeń „tożsamość” i „godność” niemal wymiennie. Tymczasem tożsamość jest odczuciem subiektywnym, podczas gdy godność jest dana wszystkim ludziom, ale zwiazana jest obiektywnie $z$ natura i prawda historyczną. Godność potomków amerykańskich niewolników przysługuje im od urodzenia, a nie polega na eliminowaniu $z$ kursów cywilizacji zachodniej wszelkich zdobyczy tej cywilizacji i podkreślaniu wspaniałości kultur rodzimych, które często były, jak na przykład aztecka, po prostu barbarzyńskie. Godność człowieka nie polega na rozwijaniu marzeń o likwidacji ograniczeń egzystencji poza granice zdrowego rozsądku. Czy można powiedzieć, że godność człowieka jest naruszona przez niemożność spełnienia każdej zachcianki? Czy godność człowieka chorego czy niesprawnego jest ograniczana przez jego lub jej niższa ,jakość życia”? I kto ma wymierzyć tę różnicę? I co należy zrobić w takiej sytuacji, skoro jedni chca ludzi w śpiączce uśmiercać, a inni ratować za wszelką cenę i czekać "cudu”? To są pytania fundamentalne, $z$ którymi liberalna demokracja nie potrafi sobie poradzić, bo straciła transcendentne źródła ocen moralnych, bo kieruje się „antropologia nieograniczona", w której zredukowano naturę człowieka niemal do zera i wypełnia ja przypadkowymi zachciankami.

Być może tutaj tkwi źródło coraz większego niepokoju dręczącego ludzi Zachodu, którzy zadają sobie pytanie „kim naprawdę jestem?”10 i szukaja odpowiedzi w domaganiu się godności w sferach co najmniej wątpliwych. Godności nie da się znaleźć ani w ubliżaniu ludziom o innym kolorze skóry, ani w rodzeniu dzieci po sześćdziesiątce, ani $\mathrm{w}$ ucieczce od macierzyństwa, w domaganiu się korzystania $z$ damskich toalet przez biologicznych mężczyzn, biciu rekordów seksualnych, tatuowaniu sobie całego ciała, wpinaniu sobie kolczyków we wszystkie dostępne i niedostępne jego części czy publikowaniu w sieci swoich nagich selfies. Jeśli nie uznamy, że godność człowieka jest darem, który zobowiazuje, darem, który wymaga szacunku dla natury, to dojdziemy do sytuacji, gdy każdy będzie miał prawo do wszystkiego, czyli do pełni chaosu. Fukuyama mimochodem zwraca na to uwagę, cytując orzeczenie sędziego Sadu Najwyższego USA Anthony'ego

\footnotetext{
10 Ibidem, s. 56.
} 
Kennedy'ego, oparte na uzasadnieniu, wolność ,jest prawem do określenia własnego pojęcia istnienia, sensu, wszechświata oraz tajemnicy ludzkiego życia" ${ }^{11}$. To pozornie liberalne podejście do natury człowieka, stanowi bowiem, jeśli je głębiej przeanalizować, usunięcie jakichkolwiek podstaw moralnych społeczeństwa. Gwoli sprawiedliwości, Fukuyama dostrzega za Philipem Rieffem, że „zanik wspólnego, wyznaczonego przez religię horyzontu moralnego pozostawił ogromna pustkę, którą wypełniaja psychologowie głoszacy nową religię psychoterapii” ${ }^{12}$. Dodać można, że wypełniaja oni tę pustkę, jedynie wywołując kolejne fale watpliwych roszczeń „godnościowych” i pogarszając sytuację.

Fukuyama słusznie zauważa postępy „rewolucji godnościowej” zachodzacej w ostatnich dziesięcioleciach, gdy lansowano dumę negritude, gdy nasilały się kampanie równouprawnienia kobiet i usuwania różnych rodzajów dyskryminacji, gdy lansowano przy okazji określenia typu „homofobia” czy „islamofobia”. Rzekomy „populistyczny nacjonalizm", jaki przypisuje Fukuyama Putinowi, Orbánowi, Kaczyńskiemu czy wreszcie Trumpowi, nie ma jednak $z$ tymi zjawiskami wiele wspólnego. Polityka Putina czy Erdoğana wynika raczej z imperialnych ciagot obu tych przywódców. Podobnie jest w pewnej mierze $z$ polityka chińska czy indyjska, a nawet $z$ Trumpem, choć w tym ostatnim przypadku jest to bardziej wykorzystanie nastrojów wykluczenia panujących wśród amerykańskiej klasy średniej i niższej klasy średniej. Podobnie polityka Orbána czy polskiego Prawa i Sprawiedliwości jest raczej skutkiem rozczarowania węgierskich i polskich „niewidzialnych ludzi” $z$ książki Ralpha Ellisona ${ }^{13}$ rządami elit demokracji liberalnej oraz stopniowym podporządkowywaniem Węgier czy Polski mocarstwom zachodnim niż samoistnego wzrostu nacjonalizmu.

Watpliwości wobec niektórych tez Fukuyamy mieszaja się jednak $z$ aprobatą innych jego spostrzeżeń. Ma on zdecydowanie rację zauważając w końcu, iż lewicowa rewolucja drążąca społeczeństwa zachodnie od lat sześćdziesiątych przyczyniła się wraz ze swoją „polityczna poprawnością" do rozwoju polityki „tożsamościowej” na prawicy ${ }^{14}$. Pytanie tylko, czy naprawdę chodzi tu o „prawicę”, czy może o obrońców wolności przed lepiej wiedzącymi inżynierami społecznej wyobraźni, dominujacymi w polityce i mediach.

11 Ibidem, s. 78 .

12 Ibidem, s. 125. Fukuyama zauważa też „nietscheański” charakter dążeń lewicy po 1968 roku, s. 144.

13 R. Ellison, Niewidzialny człowiek, Rebis, Poznań 2004.

14 F. Fukuyama, Tożsamość..., s. 150. 
W odróżnieniu od wielu lewicowych lub liberalnych politologów, Fukuyama nie gorszy się tożsamością narodową. Podkreśla, że służy ona podniesieniu bezpieczeństwa kraju jako całości, jakości rządu, któremu łatwiej dbać jest o interes wspólnoty, rozwojowi gospodarcze$\mathrm{mu}$, a także sprzyja wzrostowi zaufania w społeczeństwie. Do każdej $z$ tych funkcji można by podnieść pewne zastrzeżenia. Na przykład zaufanie w państwie narodowym może być podkopywane przez domysły, kto wśród „swoich” jest naprawdę „swój”, a kto tylko udaje. Fukuyama słusznie wiąże problemy Unii Europejskiej ze wzrostem odsetka osób obcego pochodzenia w takich krajach, jak Francja, Niemcy, Holandia czy Szwecja, a więc rosnacca heterogenicznościa ich społeczeństw, a także $z$ nacjonalistyczna reakcją na te zjawiska. Zauważa także, iż Unia Europejska nie potrafiła stworzyć ponadnarodowej tożsamości europejskiej, a obecnie jest coraz bardziej rozsadzana przez źle rozumiane skłonności partykularne. Problem w tym, że skłonności te nie sa tylko domena nowych, "nacjonalistyczno-populistycznych" sił w krajach Unii, ale sa świadoma polityką ich rząów broniących swoich interesów przed nowymi państwami członkowskimi, zwłaszcza tymi, jak Polska czy Węgry, który usiłują wydobyć się spod dominacji unijnych „centrów doskonałości”.

Fukuyama przytacza dwa argumenty przemawiające za tym, że idea państw narodowych jest przestarzała. Po pierwsze więc, w naszych czasach wiele problemów ma charakter globalny i dlatego wymagaja globalnych rozwiązan. Tyle, że rozwiązaniom tym przeciwstawiaja się nie tylko mniejsze państwa narodowe, ale głównie wielkie mocarstwa. Dobrym tego przykładem jest polityka klimatyczna Unii Europejskiej, w której większe państwa, dysponujące technologiami pozwalającymi wykorzystywać nowe źródła energii, narzucaja restrykcje ekologiczne w celu sprzedaży tych technologii, a nie w celu prawdziwej ochrony klimatu, na który Unia ma wpływ niewielki, gdyż główni truciciele Chiny, USA, Rosja i Indie - nie przejmują się względami ekologicznymi. Gdzie tu globalne rozwiazanie globalnych problemów? Po drugie, jak zauważa Fukuyama, demokracje liberalne zbudowane są na założeniu powszechnej równości ludzi, a równość ta nie zamyka się w granicach państw. Założenia demokracji liberalnych nie sa jednak przestrzegane przez wiele głównych państw świata, $z$ których państwa muzułmańskie nawet wyraźnie chca wykorzystywać te założenia do swoich celów, promując emigrację muzułmanów na teren demokracji liberalnych. W sumie, Fukuyama twierdzi jednak, że dwa przytoczone argumenty nie podważaja zalet państw opartych na tożsamości narodowej. 
Pozostaje jednak pytanie najważniejsze: czy polityka tożsamości, realizowana przez główne państwa świata $z$ coraz większym animuszem, nie zwiększy zagrożenia wojną. Wielkie mocarstwa kierują się bowiem zawsze dość specyficzna logika, w której ideologia „wolnego świata” lub rewolucji komunistycznej, a ostatnio ideologie „demokracji liberalnej”, postępu, zagrożenia klimatycznego lub tożsamości odgrywaja rolę instrumentu, a państwa mniejsze sa często zastraszane tymi hasłami ideologicznymi, tak aby nie wychodziły $z$ szeregu.

Wojciech Roszkowski Instytut Studiów Politycznych Polskiej Akademii Nauk ORCID 0000-0002-7736-2013 wojciech@roszkowski.pl 